\title{
Review: Mammary development in lactating sows: the importance of suckling
}

\author{
C. Farmer ${ }^{\dagger}$ \\ Agriculture and Agri-Food Canada, Sherbrooke R \& D Centre, 2000 College St., Sherbrooke, QC, Canada J1M OC8
}

(Received 25 July 2018; Accepted 20 November 2018)

\begin{abstract}
Mammary development takes place during the growing and gestation periods in swine but it also continues after farrowing. In fact, a significant proportion of mammary accretion occurs during lactation and is stimulated by suckling. After piglets are weaned, there is involution of the mammary glands and the process of mammogenesis starts again during the next parity. Suckling of a teat for the first 12 to $14 \mathrm{~h}$ after farrowing is not sufficient to maintain lactation, and mammary involution accompanied by alterations in gene transcription will take place. The involution process is reversible within 1 day postpartum but is not reversible if a mammary gland is unsuckled for 3 days. Mammary glands that undergo involution early in lactation do not show further involution in the post-weaning period. The action of a teat being suckled does not only affect mammary development in the ongoing lactation but it also impacts mammogenesis in the following lactation. Indeed, when a mammary gland is not suckled in first parity it has a diminished development and lower milk yield in second parity. Furthermore, it was shown that suckling of a teat for only the first 2 days postpartum in primiparous sows is sufficient to ensure optimal mammary development and milk yield from that teat in the next lactation. The behavior of nursing piglets in early lactation is also affected by whether or not a teat was previously used. Such knowledge on lactation biology is essential in order to develop the best adapted management strategies for the currently used hyperprolific sow lines and to optimize growth rate of their piglets. This review gives an update on the role of suckling for mammary development in lactating sows and on how it can affect management strategies of primiparous sows.
\end{abstract}

Keywords: involution, lactation, mammary gland, nursing intensity, piglet

\section{Implications}

Suckling of a teat is essential for mammary development in sows during lactation, as demonstrated by the irreversible involution of mammary glands after 3 days of not being suckled by piglets. Knowledge on the role of suckling for mammary development is crucial in order to develop optimal management strategies for replacement gilts and sows. We now know that a teat which is not suckled in first lactation will produce less milk in the subsequent lactation. However, if a teat is used for only the first 2 days postpartum in primiparous sows its milk yield will not be reduced in second parity. Producers can therefore decrease litter size of very thin primiparous sows after day 2 of lactation to increase their longevity in the herd without harmful effects on subsequent milk yield.

\section{Introduction}

In current swine production systems suckling piglets generally show suboptimal growth because their dam cannot

\footnotetext{
${ }^{\dagger}$ E-mail: chantal.farmer@canada.ca
}

produce enough milk (Harrell et al., 1993). Indeed, even though genetic selection led to the development of hyperprolific sow lines, it had no beneficial impact on sow milking capacity (Silalahi et al., 2017) so that each piglet now consumes less milk. It is therefore imperative to understand the factors affecting sow milk yield in order to develop strategies that will increase piglet weight gain. Milk yield is related to mammary development (Head and Williams, 1991) and one factor of utmost importance for mammogenesis and milk yield is suckling of a teat by piglets (Farmer et al., 2012). If a teat is not suckled for 3 days during lactation it will undergo irreversible involution (Theil et al., 2006) and if a teat is not suckled at all in first lactation it will produce less milk in the second lactation (Farmer et al., 2012). However, suckling for a period as short as 2 days in early lactation will ensure that milk yield in the subsequent lactation is not hampered (Farmer et al., 2017). This review will cover the process of mammary involution that takes place either after weaning or during lactation when a teat is not used. Results from recent trials on the effects of teat use in first-parity sows on their mammary development, mammary gene expression and milk yield in the next lactation will be described. The impact of use 
or non-use of a teat in first parity on nursing behavior of piglets in the subsequent parity will also be discussed. Lastly, this information will be used to suggest a best-adapted management strategy for hyperprolific gilts that are overly thin.

\section{The ongoing cycle of mammary gland development}

Some mammary development takes place before puberty in gilts (Sorensen et al., 2002) but more extensive mammary development occurs during the last third of pregnancy (Hacker and Hill, 1972; Kensinger et al., 1982; Sorensen et al., 2002) and throughout lactation (Kim et al., 1999). During the last third of gestation major histological changes take place in mammary tissue, with adipose and stromal tissues being replaced by lobuloalveolar tissue in order for milk to be secreted (Hacker and Hill, 1972; Kensinger et al., 1982; Ji et al., 2006). There is still important development of mammary tissue in lactation. Mean mammary weight of functional glands increases linearly by $57 \%$ between days 5 and 21 of lactation (Kim et al., 1999). Furthermore, there are indications that the extent of mammary development in lactation could be linked to the amount of post-ejection massage from nursing piglets (Thodberg and Sorensen, 2006). Indeed, it has been postulated in early work that each piglet could act as its own regulator of milk availability in the next suckling via the amount of post-ejection massage that it performs on the gland that it uses (Algers and Jensen, 1985). After weaning, there is a rapid and drastic involution of the mammary glands (Ford et al., 2003) so that the process of mammary development undergoes a new cycle during the subsequent gestation and lactation periods. The following section will cover the events taking place during mammary involution in more details.

\section{Mammary involution}

\section{At weaning}

The process of weaning the piglets from the sow leads to an abrupt cessation of milk removal, hence involution of mammary glands. Weaning is characterized by a rapid regression of mammary tissue in the first 7 days (Ford et al., 2003). During that 7-day period there is a $69 \%$ decrease in wet weight of parenchymal tissue and a $67 \%$ decrease in parenchymal DNA (Ford et al., 2003). The most dramatic changes occur in the first 2 days after weaning. The crosssectional area, gland weight and parenchymal DNA in mammary tissue decrease markedly (Ford et al., 2003). In the initial phase of involution (weaning to day 2), milk is no longer removed from the glands, thereby inducing milk stasis. There is an initial engorgement of mammary glands (day 1) until milk present in the lumen starts being reabsorbed (Cross et al., 1958). It was postulated that, in the absence of milk removal, an autocrine feedback inhibitor of lactation accumulates in the lumen of alveolar cells to inhibit further milk secretion (Wilde et al., 1995). Marked changes in milk composition occur during that early weaning period, namely, the dry matter, fat and protein contents increase whereas lactose content decreases. Furthermore, there is an increase in the sodium $(\mathrm{Na}) /$ potassium $(\mathrm{K})$ ratio in milk, indicative of leakage of mammary tight junctions and concentrations of prolactin decrease while those of IGF-1 increase (Farmer et al., 2007). In the second phase of involution (days 2 to 4 or 5 post-weaning) there are small changes in mammary tissue that coincide with the limited alterations observed in milk metabolites (Atwood and Hartmann, 1995). Finally, in the last phase of involution (days 4 or 5 until day 7 post-weaning), only limited mammary secretions that are very viscous can be collected (Atwood and Hartmann, 1995). At this stage, very few alveolar structures remain (Cross et al., 1958) and a last decrease in mammary tissue and parenchymal DNA is observed (Ford et al., 2003).

The number of days in lactation affects the process of mammary involution. Tight junctions between mammary epithelial cells become leaky as lactation progresses from days 22 to 44 (Farmer et al., 2007). It was suggested that in a 44-day lactation the onset of mammary involution occurred before weaning because piglets had access to creep feed starting on day 22 , which decreased their hunger and suckling intensity.

\section{During lactation}

Mammary involution does not only occur after weaning but can also take place during lactation. Mammary glands that are not suckled in the first few days of lactation will regress at a rate similar to that of mammary glands regressing after weaning (Kim et al., 2001). When a gland is not suckled, there is a $67 \%$ reduction in wet weight of mammary tissue in the first 7 to 10 days of lactation and these unsuckled mammary glands show no further loss of mammary parenchyma post-weaning (Ford et al., 2003). The drastic and important involution of mammary glands that are not suckled in early lactation led to the original hypothesis that the process of unsuckled glands becoming non-functional may not be reversible after a few days (Kim et al., 2001). It was later shown that regression of unsuckled mammary glands during early lactation is reversible during the first $24 \mathrm{~h}$ but is irreversible after 3 days (Theil et al., 2005). Yet, glands that were sealed for either 24 or $72 \mathrm{~h}$ after farrowing had lower expression levels of receptors for $\alpha$-lactalbumin and prolactin, showed less proliferation of cells, and had greater messenger RNA (mRNA) abundance for IGF-binding protein-5 (IGFBP-5) than glands that were suckled regularly. Such findings are in accordance with the fact that glands that were unsuckled for $24 \mathrm{~h}$ had a lower milk yield throughout lactation compared with regularly suckled glands. In a later trial, glands were as follows: (1) unsuckled, (2) suckled until 12 to $14 \mathrm{~h}$ postpartum or (3) suckled regularly (Theil et al., 2006). Visual scoring indicated that unsuckled glands or glands suckled only for 12 to $14 \mathrm{~h}$ regressed during lactation, whereas regularly suckled glands did not. Cell proliferation was measured in biopsies of mammary glands obtained from 5 days before until 6 days after farrowing. Cell turnover was 
greatest (at 13.1\%) before parturition, decreased postpartum and then, between days 1 and 6 after farrowing, either remained low at $\sim 5.6 \%$ (in unsuckled glands) or increased to $9.9 \%$ (in glands suckled regularly or suckled for 12 to $14 \mathrm{~h}$ ). Nevertheless, suckling of a teat for 12 to $14 \mathrm{~h}$ after farrowing was not adequate for lactation to be initiated and maintained until $36 \mathrm{~h}$ postpartum. Such a finding can be explained by the fact that it is at $\sim 34 \mathrm{~h}$ postpartum that copious milk starts to be secreted (Theil et al., 2014), coinciding with the second stage of lactogenesis. The first stage of lactogenesis is characterized by the differentiation of epithelial cells into lactocytes that have the capacity to synthesize milk constituents, whereas the second stage of lactogenesis marks the onset of copious milk secretions. This last stage is hence associated with secretory activation instead of secretory differentiation (Pang and Hartmann, 2007). Theil et al. (2006) also looked at the mRNA abundance for specific genes. The expression level of prolactin receptors decreased post-farrowing and that of IGFBP-5 increased for both unsuckled glands and glands suckled for 12 to $14 \mathrm{~h}$, whereas no such changes were seen in glands that were suckled regularly. The key roles of the prolactin (positive) and IGFBP-5 (negative) receptors for the maintenance of lactation in sows is therefore evident. This also corroborates previous findings in transgenic mice whereby IGFBP-5 was demonstrated to be a determinant factor in coordinating mammary cell death (Flint et al., 2005).

\section{The importance of suckling}

During lactation milk must be removed from the mammary glands in order for them to remain functional, hence, the extent of suckling by piglets is a major stimulator for the growth of mammary glands (Hurley, 2001). The size of a mammary gland (i.e. gland weight or DNA content) and the growth rate of the piglet suckling that gland are positively correlated (Kim et al., 2000; Nielsen et al., 2001). Yet, these two factors are obviously interrelated as heavier piglets likely have a greater ability to perform post-ejection massage of the glands, hence stimulating future milk yield. Sows producing more milk ( 5.25 v. $4.46 \mathrm{~kg}$ average piglet weight gain from days 2 to 21 of lactation) also had more parenchymal DNA and parenchymal RNA per mammary gland at the end of lactation than sows with a lower milk yield (Farmer et al., 2010). Seven days after weaning, it was observed that mammary glands that had been used by piglets and remained functional until the end of lactation were larger than unsuckled glands (Ford et al., 2003). Taking into account that suckled glands undergo substantial growth during lactation (approximately doubling their size), reaching a peak at the end of lactation (Kim et al., 1999), it is apparent that they must be larger than unsuckled glands at the onset of the involution process taking place after weaning. This observation leads to the question of whether there could be a possible beneficial effect of a teat being used in first parity on the extent of its development (and milk yield) in second parity. Fraser et al. (1992) first attempted to elucidate that question by undertaking a project where the rear teats of sows were taped in first lactation and growth rate of piglets suckling either the front or the rear teats in second lactation was determined. It is known that piglets suckling front teats are generally heavier than piglets suckling rear teats (Dyck et al., 1987), and the difference in weight gain between piglets suckling the front $v$. the rear teats was even greater in sows that had previously taped rear teats. Differences in BW gain between the two groups were greater in the first compared with the $2^{\text {nd }}$ or $3^{\text {rd }}$ weeks of lactation (Fraser et al., 1992). These findings suggested a beneficial effect of teats being used in first parity on their development in the next parity. However, there was a confounding effect of treatment with teat location on the udder which cannot be overlooked.

\section{Teat use and sow mammary development}

It is only in 2012 that a clear demonstration was made that an unused gland in first parity will have impaired development and lower milk yield in second lactation (Farmer et al., 2012). To achieve that objective a project was carried out where either the same teats or different teats were sealed in both first and second parities. This was designed so that piglets in second lactation had access to teats that were either previously suckled or unsuckled. The growth rate of piglets in second parity differed between the two groups of sows. Suckling from a teat that was used in parity one led to a $1.12 \mathrm{~kg}$ greater piglet BW at 56 days of age in parity 2 compared with suckling a previously unused teat. Furthermore, growth rate of piglets between days 2 and 4 of lactation (day 1 being the day of farrowing) was already significantly different, thereby suggesting a potential beneficial effect on colostrum or early milk yield. Piglets suckling teats that were previously used gained $0.43 \mathrm{~kg}$ in BW, compared with $0.35 \mathrm{~kg}$ for piglets suckling previously unused teats, over that 2-day period.

Differences in terms of mammary development and mammary gene expression were also apparent due to treatment. On day 17 of the second lactation, mammary glands that were previously suckled had more parenchymal tissue per gland and greater parenchymal DNA and RNA contents per gland, whereas extraparenchymal tissue mass was unaffected (Table 1; Farmer et al., 2012). Parenchymal tissue from previously suckled glands also showed a greater mRNA abundance for the prolactin receptor. Results indicated the occurrence of both increased number and increased metabolic activity of parenchymal cells from glands that were previously used, which coincides with the greater weight gain of piglets suckling those teats. Differences were seen between the first and second parity but it is not known if such would also be the case between the second and third or later parities. Taking into account the fact that mammary development during lactation is greater for primiparous than multiparous sows (Nielsen et al., 2001), one may expect that differences between previously suckled and unsuckled teats 
Table 1 Mammary composition in second-parity sows of four functional glands that were either previously suckled (suckled, $\mathrm{n}=16$ ) or not (not suckled, $\mathrm{n}=16$ ) in first lactation

\begin{tabular}{|c|c|c|c|}
\hline \multirow[b]{2}{*}{ Items } & \multicolumn{2}{|c|}{ Treatment } & \multirow[b]{2}{*}{ SEM $^{1}$} \\
\hline & Suckled & Not suckled & \\
\hline Extraparenchymal tissue (g) & 692.5 & 714.3 & 48.7 \\
\hline Parenchymal tissue $(\mathrm{g})$ & $3004.1^{c}$ & $2608.7^{d}$ & 141.7 \\
\hline Parenchymal tissue/teat (g) & $800.4^{a}$ & $641.6^{\mathrm{b}}$ & 24.5 \\
\hline DM (\%) & 20.4 & 20.6 & 0.3 \\
\hline Fat $^{2}(\%)$ & 37.9 & 37.6 & 0.8 \\
\hline Fat $(g)$ & 234.9 & 205.7 & 15.1 \\
\hline Protein $^{2}(\%)$ & 52.0 & 52.9 & 0.8 \\
\hline Protein $(\mathrm{g})$ & $317.0^{c}$ & $283.3^{d}$ & 13.9 \\
\hline $\mathrm{DNA}^{2}(\mathrm{mg} / \mathrm{g})$ & 11.1 & 10.6 & 0.3 \\
\hline DNA (g total) & $6.77^{c}$ & $5.73^{d}$ & 0.37 \\
\hline DNA (g/teat) & $1.80^{\mathrm{a}}$ & $1.41^{\mathrm{b}}$ & 0.07 \\
\hline $\mathrm{RNA}^{2}(\mathrm{mg} / \mathrm{g})$ & 24.7 & 25.4 & 0.6 \\
\hline RNA (g total) & 14.9 & 13.6 & 0.6 \\
\hline RNA (g/teat) & $3.99^{\mathrm{a}}$ & $3.34^{b}$ & 0.10 \\
\hline
\end{tabular}

Sows were slaughtered on day 17 of lactation. Adapted from Farmer et al. (2012).

$\mathrm{a}, \mathrm{b}$ Means within a row without a common superscript differ $(P<0.01)$.

c,d Means within a row without a common superscript tend to differ $(P<0.10)$.

${ }^{1}$ Maximum value.

${ }^{2}$ Expressed on a dry matter (DM) basis.

would be lesser between later parities. Current findings are therefore most important for the management of primiparous sows. This is of great importance due to the fact that with the current hyperprolific sow lines, the burden of feeding all the suckling piglets may overtax first-parity sows that have a poor body condition. In that context the option of removing piglets from the sow may be an avenue considered. However, the next question then arises: is there a minimum period of time that a piglet must suckle a teat in first parity to avoid hindering development of that teat in second lactation?

\section{Duration of teat use and sow mammary development}

Farmer et al. (2017) undertook a project where first parity sows had their piglets removed on day 2, 7 or 21 of lactation and second lactation was 21 days. In both first and second lactation, litters were standardized to 12 piglets keeping only 12 functional teats by taping any surplus teats. Weight gain of piglets in second lactation was obtained and mammary biopsies were performed on 10 sows per treatment on day 110 of gestation and day 21 of lactation. Parenchymal tissue samples were used to determine mRNA abundance for prolactin, long form of the prolactin receptor, signal transducers and activators of transcription $5 A$ and $5 B$ (STAT5A and STAT5B), $\alpha$-lactalbumin and IGFBP-5 genes. Increasing the duration of lactation from 2 days to 7 or 21 days in firstparity sows did not improve growth rate of their piglets in the subsequent lactation. This suggests that suckling of a teat for
2 days in primiparous sows is sufficient to ensure optimal mammary development so that piglet growth is not hindered during the subsequent lactation. Some treatment effects on mammary gene expression were present. The most important ones being (1) greater mRNA abundance for the prolactin gene on day 110 of gestation in sows with a previous lactation of 21 days compared with 7 days, and (2) greater mRNA abundance for the STAT5B gene on day 21 of lactation for sows with a previous lactation of seven compared with 2 days. Yet, these changes were not large enough to bring about differences in milk yield, as evidenced by the similar piglet growth rates.

As stated previously, Theil et al. (2006) demonstrated that suckling for the first 12 to $14 \mathrm{~h}$ postpartum was not sufficient to initiate and maintain lactation in sows. Current results now indicate that a $48 \mathrm{~h}$ period of suckling allows enough of the lactation process to take place so that the lactation performance in the subsequent lactation is not negatively affected. Such findings are of importance for the management of first-parity sows.

\section{Previous teat use and nursing behavior of piglets}

The behavior of nursing piglets in early lactation is also affected by whether or not a teat was previously used. The development of nursing behavior in newborn piglets is an intricate process (de Passillé and Rushen, 1988 and 1989) and knowing that a previously unused teat produces less milk in parity two, it could be hypothesized that non-use of a teat in first parity could affect the behavior of suckling piglets in the next lactation. That was indeed found to be the case. On day 3 of lactation, piglets suckling a previously unused teat had more aggressive behavior, a longer duration of postejection massage, and a greater incidence of missed nursings compared with piglets suckling a teat that was previously used (Farmer et al., 2012). The combination of those behaviors suggests that piglets were more eager to obtain milk, and therefore, hungrier. Jensen et al. (1998) showed that a longer period of teat massage after milk ingestion reflects a greater hunger status of piglets. Furthermore, English and Bilkei (2004) demonstrated that in large litters, low-birthweight piglets missed more nursings and spent more time in teat disputes than their heavier littermates, thereby suggesting that a greater level of hunger leads to more aggressive encounters.

It is known that piglets show preferences for certain teats on the udder, translating into greater incidences of fighting to obtain access to these teats (de Passillé and Rushen, 1989). Teat preferences can be linked to milk yield as piglets prefer the more anterior teats (de Passillé and Rushen, 1989) that are also more productive (Kim et al., 2000). Interestingly, in second lactation, neonatal piglets were able to differentiate the more productive previously used teats from the less productive teats that were not used in first lactation (Devillers et al., 2016). This was demonstrated in a study where in first lactation more than half of the sow's teats were 
sealed with tape and six teats remained unblocked. In second lactation none of the teats were sealed and litter size was standardized to eight piglets. There were therefore more piglets than the number of teats that had been previously used and behavior of piglets was observed on days 2 and 10 of lactation. Sealing of teats with tape affected the behavior of piglets on day 2 only, coinciding with the period where teat order is being established and piglets choose and compete for higher-producing teats (de Passillé and Rushen, 1988). In second lactation, the total number of fights was greater and the percentage of time the teat was suckled during post-massage was longer for previously used teats compared with previously unused teats. Furthermore, previously used teats had a greater occupancy rate. Piglets that suckled preferentially from previously used teats on day 2 of lactation also had a significantly greater growth rate until day 56 than piglets favoring previously unused teats (23.66 v. $21.32 \pm 0.59 \mathrm{~kg}$ ). Results therefore confirmed that teats used in first lactation produce more milk in second lactation, and also showed that piglets are able to detect this difference early on.

\section{Conclusion}

The process of mammary development is cyclic, with mammary accretion taking place during gestation and lactation, followed by involution and new development occurring in the next parity. Suckling is the main stimulus required for teats to remain functional and a gland that is not suckled will undergo involution. This can occur either at weaning or during lactation. When a teat is not suckled in first parity it will impair its development and productivity in the subsequent lactation. Furthermore, nursing behavior of piglets in second parity will be affected so that, when given a choice, piglets will fight more to have access to previously used teats. Suckling of a teat for the first 12 to $14 \mathrm{~h}$ postpartum is not sufficient to initiate and maintain lactation in sows. Yet, it is now known that a 48-h period of suckling during the first lactation is enough to avoid any negative effects on its milk yield in second lactation. This information is particularly important because hyperprolific sow lines are currently used and producers are faced with the question of what is the best litter size for first-parity sows in order to ensure their longevity and optimal reproductive performance.

\section{Acknowledgments}

The author wishes to thank Dr Walt Hurley for his review of the current manuscript.

\section{Declaration of interest}

There is no conflicts of interest involved with this paper.

\section{Ethics statement}

This paper is a review of published information. No new ethical approval was required.

\section{Software and data repository sources}

No new data were generated in this paper.

\section{References}

Algers B and Jensen P 1985. Communication during suckling in the domestic pig. Effects of continuous noise. Applied Animal Behaviour Science 14, 49-61. Atwood CS and Hartmann PE 1995. Assessment of mammary gland metabolism in the sow. III. Cellular metabolites in the mammary secretion and plasma following weaning. Journal of Dairy Research 62, 221-236.

Cross BA, Goodwin RFW and Silver IA 1958. A histological and functional study of the mammary gland in normal and agalactic sows. Journal of Endocrinology 17, 63-74.

de Passillé AM and Rushen J 1988. Ontogeny of teat fidelity in pigs and its relation to competition at suckling. Canadian Journal of Animal Science 68, 325-338.

de Passillé AM and Rushen J 1989. Suckling and teat disputes by neonatal piglets. Applied Animal Behavior Science 22, 23-38.

Devillers N, Giraud D and Farmer C 2016. Neonatal piglets are able to differentiate more productive from less productive teats. Applied Animal Behavior Science 174, 24-31.

Dyck GW, Swierstra EE, McKay RM and Mount K 1987. Effect of location of the teat suckled, breed and parity on piglet growth. Canadian Journal of Animal Science 67, 929-939.

English JGH and Bilkei G 2004. The effect of litter size and littermate weight on pre-weaning performance of low-birth-weight piglets that have been crossfostered. Animal Science 79, 439-443.

Farmer C, Amezcua M, Bruckmaier R, Wellnitz 0 and Friendship R 2017. Does duration of teat use in first parity affect milk yield and mammary gene expression in second parity? Journal of Animal Science 95, 681-687.

Farmer C, Knight C and Flint D 2007. Mammary gland involution and endocrine status in sows: effects of weaning age and lactation heat stress. Canadian Journal of Animal Science 87, 35-43.

Farmer C, Palin M-F and Hovey R 2010. Greater milk yield is related to increased DNA and RNA content but not to mRNA abundance of select genes in sow mammary tissue. Canadian Journal of Animal Science 90, 379-388.

Farmer C, Palin M-F, Theil PK, Sorensen MT and Devillers N 2012. Milk production in sows from a teat in second parity is influenced by whether it was suckled in first parity. Journal of Animal Science 90, 3743-3751.

Flint DJ, Boutinaud M, Tonner E, Wilde CJ, Hurley W, Accorsi PA, Kolb AF, Whitelaw CBA, Beattie J and Allan GJ 2005. Insulin-like growth factor binding proteins initiate cell death and extracellular matrix remodeling in the mammary gland. Domestic Animal Endocrinology 29, 274-282.

Ford J A Jr, Kim SW, Rodriguez-Zas SL and Hurley WL 2003. Quantification of mammary gland tissue size and composition changes after weaning in sows. Journal of Animal Science 81, 2583-2589.

Fraser D, Thompson BK and Rushen J 1992. Teat productivity in second lactation sows: influence of use or non-use of teats during the first lactation. Animal Production 55, 419-424.

Hacker RR and Hill DL 1972. Nucleic acid content of mammary glands of virgin and pregnant gilts. Journal of Dairy Science 55, 1295-1299.

Harrell RJ, Thomas MJ and Boyd RD 1993. Limitations of sow milk yield on baby pig growth. In Proceedings of the Cornell Nutrition Conference for Feed Manufacturers, 19-21 October 1993, Rochester, NY, pp.156-164.

Head RH and Williams IH 1991. Mammogenesis is influenced by pregnancy nutrition. In Manipulating pig production III ((ed. ES Batterham), pp. 33. Australasian Pig Science Association, Werribee, VIC, Australia.

Hurley WL 2001. Mammary gland growth in the lactating sow. Livestock Production Science 70, 149-157.

Jensen P, Gustafsson M and Augustsson H 1998. Teat massage after milk ingestion in domestic piglets: an example of honest begging? Animal Behavior 55, 779-786.

Ji F, Hurley WL and Kim SW 2006. Characterization of mammary gland development in pregnant gilts. Journal of Animal Science 84, 579-587.

Kensinger RS, Collier RJ, Bazer FW, Ducsay CA and Becker HN 1982. Nucleic acid, metabolic and histological changes in gilt mammary tissue during pregnancy and lactogenesis. Journal of Animal Science 54, 1297-1308. 
Kim SW, Easter RA and Hurley WL 2001. The regression of unsuckled mammary glands during lactation in sows: the influence of lactation stage, dietary nutrients, and litter size. Journal of Animal Science 79, 2659-2668.

Kim SW, Hurley WL, Han IK and Easter RA 1999. Changes in tissue composition associated with mammary gland growth during lactation in sows. Journal of Animal Science 77, 2510-2516.

Kim SW, Hurley WL, Han IK and Easter RA 2000. Growth of nursing pigs related to the characteristics of nursed mammary glands. Journal of Animal Science 78, 1313-1318.

Nielsen OL, Pederson AR and Sorensen MT 2001. Relationships between piglet growth rate and mammary gland size of the sow. Livestock Production Science 67, 273-279.

Pang WW and Hartmann PE 2007. Initiation of human lactation: secretory dif ferentiation and secretory activation. Journal of Mammary Gland Biology and Neoplasia 12, 211-221.

Silalahi P, Tribout T, Billon Y, Gogué J and Bidanel JP 2017. Estimation of the effects of selection on French Large White sow and piglet performance during the suckling period. Journal of Animal Science 95, 4333-4343.
Sorensen MT, Sejrsen K and Purup S 2002. Mammary gland development in gilts. Livestock Production Science 75, 143-148.

Theil PK, Labouriau R, Sejrsen K, Thomsen B and Sorensen MT 2005. Expression of genes involved in regulation of cell turnover during milk stasis and lactation rescue in sow mammary tissue. Journal of Animal Science 83, 2349-2356.

Theil PK, Lauridsen C and Quesnel H 2014. Neonatal piglet survival: impact of sow nutrition around parturition on fetal glycogen deposition and production and composition of colostrum and transient milk. Animal 8, 1021-1030.

Theil PK, Sejrsen K, Hurley WL, Labouriau R, Thomsen B and Sorensen MT 2006. Role of suckling in regulating cell turnover and onset and maintenance of lactation in individual mammary glands of sows. Journal of Animal Science 84, 1691-1698.

Thodberg K and Sorensen MT 2006. Mammary development and milk production in the sow: effects of udder massage, genotype and feeding in late gestation. Livestock Science 101, 116-125.

Wilde CJ, Addey CVP, Boddy LM and Peaker M 1995. Autocrine regulation of milk secretion by a protein in milk. Biochemistry Journal 305, 51-58. 